\title{
Yerel Yönetimlerde E-Belediye Uygulamaları: Büyükşehir Belediyeleri Üzerine Bir İçerik Analizi
}

\author{
Eren KARATAŞ* \\ Ahmet TARHAN** (D)
}

ÖZ

Türk kamu yönetiminde belediyeler, toplumsal hayatın gelişmesine ve değişmesine paralel bir şekilde örgütsel yapılarında ve toplumsal hayat içerisindeki yerlerinde çeşitli değişimler yaşamışur. Vatandaş ve belediyeler arasındaki mekânsal ve toplumsal yakınlık, belediyeleri merkezi yönetim içerisinde tamamlayıcı bir unsur olarak konumlandırmaktadır. Yaşanan bu gelişmeler bilgi ve iletișim teknolojilerinin de gelișmesiyle beraber yönetimsel anlamda çeșitli sorunları beraberinde getirmiștir. Türk kamu yönetiminde, yönetim ve ilgili kamuları arasındaki etkileşimi ve iletişimi olumsuz yönde etkileyen en önemli sebepler olarak geleneksel yönetim anlavıșının doğasında var olan kağıt temelli, formalitelere davanan ağır işleyen bürokratik yapı olarak ön plana çıkmaktadır. Özellikle 1980'li ylllardan itibaren bilgi ve iletişim teknolojilerinde yaşanan gelişmeler kamu yönetimindeki hizmet sunumunda radikal değişimlere yol açmıştır. Bu doğrultuda ulusal anlamda e-devlet; yerel anlamda ise e-belediye uygulaması etkin ve verimli hizmet amacıyla modern yönetim anlayışını gerçekleştirmede hayati bir rol üstlenmektedir.

Araştırma kapsamında Türkiye sınırları içerisinde bulunan 30 büyükşehir belediyesinin sunduğu "e-hizmetler" 02 Aralık 202008 Aralı 2020 tarihleri arasında hem kurumsal web sayfaları üzerinden hem e-devlet platformu üzerinden içerik analizi yöntemine tabi tutularak literatürde e-devlet olgunluk modeli/gelişim aşamaları olarak adlandırılan bilgilendirme, etkileşim, işlem ve bütünleșme așamaları kapsamında incelenmiștir. Elde edilen sonuçlara göre belediyeler ilgili paydașlarına yönelik çeșitli uygulamalar sunmakta ve bu uygulamalara kurumsal web sayfalarında birbirine benzer isimlerle yer vermektedir. Ek olarak belediyeler bilgilendirme, etkileşim ve ișlem aşamalarına yönelik hizmetleri kurumsal web sayfalarında büyük oranda sunduğu görülürken; e-devlet platformu üzerinde etkileşim ve işleme yönelik hizmet sunan belediyelerin az sayıda olması dikkat çekmektedir.

Anahtar Kelimeler: E-Devlet, E-Belediye, E-Devlet Gelişim Așamaları, Belediyeler, İçerik Analizi

\section{E-Municipality Applications in Local Government: A Content Analysis on Metropolitian Municipalities}

\begin{abstract}
In Turkish public administration, municipalities have experienced various changes in their organizational structure and place in communal life in parallel with the development and transform of social life. The spatial and communal cohesion between citizens and municipalities position the municipalities as a complementary factor within the central government. These developments, along with the development of information and communication technologies, have brought various administrative problems. Developments in information and communication technologies, especially since the 1980 s, have led to radical changes in providing service in public administration. In this direction, in the national sense, e-government application; whereas in the local sense, the e-municipality application plays a vital role in realizing the modern administration approach for effective and efficient service.

In the study, the 30 metropolitan municipalities in Turkey were examined by both corporate website applications as well as applications in e-government platform in the content analysis method. In the literature, e-government maturity model and egovernment development stages have been examined together with their titles within the framework of information, interaction, process and integration stages. According to the results, municipalities offer various applications for their respective stakeholders and include these applications with similar names on their corporate web pages. In addition, it is seen that the services for information, interaction and transaction stages are largely provided on corporate web pages; it is noteworthy that the number of municipalities that provide services for interaction and processing on the e-government platform is few.

Keywords: E-Government, E-Municipality, E-Government Development Stages, Municipalities, Content Analysis
\end{abstract}

\section{Giriş}

İnsanoğlu tarihsel gelişim süreci boyunca yaşadığı değişimler ve gelişmeler sonucunda sosyal, politik ve ekonomik anlamda köklü değişimler yaşamıştır. Yaşadığ1 bu değişimler insanoğlunun var olan yaşam pratiklerine ve örgütlenme biçimlerine göre farklı şekilde adlandırılmalarına neden olmuştur. İnsanoğlu, İlkel Toplum'dan Tarım Toplumu'na, Tarım Toplumu'ndan Sanayi Toplumu'na geçiş yaparak farklı

\footnotetext{
* Lisansüstü öğrenci, Selçuk Üniversitesi Sosyal Bilimler Enstitüsü, erenkrtss@gmail.com

** Prof. Dr., Selçuk Üniversitesi, tarhan@selcuk.edu.tr

Makalenin Gönderim Tarihi: 18.12.2020; Makalenin Kabul Tarihi: 01.01.2021
} 
aşamaları tecrübe edinmiştir. Tecrübe edindiği bu gelişim aşamalarından ilki insanlan ilkel yaşamdan toprağa ve yerleşik düzene bağlayan Tarım Toplumu'na geçiş; ikincisi Tarım Toplumu'ndan kitlesel üretimin, tüketimin ve eğitimin ön planda olduğu Sanayi Toplumu'na geçiş; üçüncüsü ise kitlesel refahın, bilginin ve nitelikli insan sermayesinin önem kazandığı Bilgi Toplumu aşamasıdır (Çoban, 1996, s. 5-6). Bilgi Toplumu'na geçilmesiyle birlikte 1980'li yıllardan itibaren yaşanan ve halen gelişimini sürdüren teknolojik devrim gerek bilgiye erişimi gerekse erişim yolundaki yapılanmayı ve süreçleri büyük bir değişime uğratmıştır (Bensghir, 2000, s. 33).

Bilgi ve iletişim teknolojilerinde yaşanan gelişmeler sadece bireysel anlamda toplumsal hayatı değil, aynı zamanda devletler ve yurttaşlan arasındaki etkileşimi de dönüşüme uğratmıştır (Chun vd., 2010, s. 1). Bilgi ve iletişim teknolojilerindeki bu önemli gelişmeler kamu yönetimindeki bürokratik modeli, hükümetleri, kamu kuruluşlanını ve aygıtlarının verimliliğini arttırmak için yeniden yapılanmalarını zorunluluk haline getirmiştir (Roblek vd., 2020, s. 281).

Toplumun desteğini ve güvenini sağlamak kamu kuruluşları için yaşamsal önem taşımaktadır. Toplumsal destek, kamu kuruluşlarının başarısının ilk koşulu olduğu ifade edilmektedir (Yalçındağ, 1987, s. 60). Bu gerçekten hareketle kamu kuruluşları bilgi ve iletişim teknolojilerinin kendilerine sunduğu fırsatlardan yararlanarak vatandaşlarına sundukları hizmetin kalitesi, hızı ve verimliliğini artırarak toplumun desteğini ve güvenini kazanma yoluna gitmişlerdir.

Kamu yönetimi ve bağlı kurumları arasında halka ulaşma açısından belediyeler köprü görevi görmektedirler. Hatta halkla en yakın yönetim birimi belediyeler olarak ifade edilmektedir (Özüpek, 2003, s. 28). Bu kabulden hareketle çalısmada belediyelerin hizmetlerini ulaştırmada bilgi ve iletişim teknolojilerinin sunduğu önemli bir firsat olan e-devlet hizmetlerinden ne ölçüde yararlandıkları sorgulanmaktadir.

Araştırma literatürde genel olarak e-belediye uygulaması e-devlet uygulamasının alt grupların biri olarak kabul görmesinden hareketle (Scoot, 2005; Moon \& Norris, 2005; McMillan, 2004; Holden vd., 2003), ülkemizde faaliyet gösteren 30 büyükşehir belediyesinin e- İçişleri Bakanlığı'nın e-belediye sistemine üyelik durumlan, devlet hizmetlerini kurumsal web sayfalarından nasıl sundukları, bu hizmetlere hangi başlıklar altında yer verdikleri, e-devlet hizmetlerinin "bilgilendirme", "işlem" ve "etkileşim" adımlarından hangisinde daha çok toplandığ ve e-devlet platformu ile ne ölçüde "bütünleşme" sağladığına odaklanılmaktadır. İçerik çözümlemesi yönteminin kullanıldı̆̆1 çalışmada verilerin kodlanması ve değerlendirilmesi 02-08 Aralık 2020 tarihleri arasında gerçekleştirilmiştir ve elde edilen bulgular literatürde tarţ̧ıllan konular üzerinden yorumlanmışır.

\section{Gelenekselden Modern Belediyeciliğe Dönüşüm: E-Belediye}

Devletin görev, yetki ve sorumluluk alanı göz önüne getirildiğinde kapsadığı bu alan çok büyük bir sinırı meydana getirmektedir. Bu noktada devletin hem görev ve yetkilerini tam anlamiyla gerçekleştirebilmesi için hem de kamu hizmetlerine yönelik toplumsal ihtiyacı, merkezi idareden daha etkin ve verimli bir şekilde tespit edebilme imkanından dolay1 (Tortop, 1985, s. 3) 1930 yilında 1580 sayll Belediye Kanunu ile mahalli idareler kurulmuştur.

Yerel yönetimlerin merkezi yönetim içerisinde görev ve sorumlulukları kurulduğu ilk yıllarda belli başlı idari görevlerden ibaret iken; toplumsal yaşamda meydana gelen çeşitli değişimler sonucunda hem yerel yönetimlerin yapılanması hem de yerel yönetimlere yönelik beklenti ve ihtiyaçlar da değişime uğramıştır. $\mathrm{Bu}$ durumu somutlaştrrmak gerekirse; Cumhuriyetin ilk ylllarında görev ve sorumluluk alanları imar ve temizlik gibi faaliyetlerle sınırlı olan yerel yönetimler, 1950 ve 1970’li yıllar arasında yükselen kentleşme olgusuyla beraber halkın ekonomik sorunlarının çözümüne de yönelmiştir (Dönmez, 1995, s. 172). Dolayısıyla bu açıdan yola çıkılarak bir değerlendirme yapılacak olursa kentleşme olgusunun artmasıyla beraber yerel yönetimlerin merkezi yönetim içerisindeki rolü, merkezi yönetimin yereldeki tamamlayıcısı olarak dönüştügünün göstergesi olabilir.

Yerel yönetimlerde halk ve yönetim ilişkisini başka bir boyuta taşıyan diğer gelişme ise belediye başkanlarının halk tarafından seçilmesi olmuştur. Ülkemizde 1961 yllına kadar belediye başkanları belediye meclisleri tarafından seçilmekteydi; 1965 yllından sonra belediye başkanları halk tarafindan seçilmeye başlanmıştır (Tortop, 1985, s. 8). Bu gelişmeyle birlikte halkın yönetime katılımının arttığ1 ve daha demokratik bir yönetim anlayışının gelişmesine yönelik zemin oluştuğu yorumu yapılabilir. 
Yerel yönetimlerin toplumsal yaşam içerisindeki varllğının dönüşüme uğradığı ve örgütsel yapının da bu dönüşüme paralel olarak biçimlendiği bu yıllarda yerel yönetimlerin görev ve sorumluluklarını tam anlamıyla yerine getirememesine yönelik sebepler literatür incelendiğinde genel olarak yerel yönetimlerin görev, yetki ve sorumluluklarını yerine getirmek için gerekli olan mali kaynakların yetersizliği ile birlikte örgütlenme ve personel sorunlarına yönelik sorunlarda yoğunlaştığ1 görülmektedir (Yalçındağ, 1991, s. 126-128; Tortop, 1985; Tamer, 1995, s. 246-247; Nohutçu \& Balc1, 2005, s. 59) Ek olarak Yalçındağ (1991) araşturmasında yerel yönetimlerin kendi kendini yönetmesi, halkın katulımı, denetimi ve temsilini gerçekleştirmesi, yönetsel açıdan demokratik anlamda yeterli olmadığı, kentleşme olgusu ve şehirleşmeye paralel bir şekilde toplumsal gelişmenin de artması sonucunda ön plana çıkan yönetsel ve örgütsel açıdan etkinlik ve verimliliği sağlama noktasında sorunların olduğuna değinerek yerel yönetimlerin yeniden yapılanmasına yönelik gerekliliğe dikkat çekmiştir.

Yalçındağ (1987, s. 69), yerel yönetimlerin çözüm bulması gereken en önemli hususlardan birisi de tarihten miras kalan bürokrasi-halk zıtlaşmasının ortadan kaldırılması olduğuna değinerek yerel yönetimlerin görev ve sorumluluklarını yerine getirme noktasında geleneksel yönetim anlayışının temelinde var olan bürokratik yapıdaki hantal işleyişini ortadan kaldırması ve halkla uyum sağlamaya yönelik adımlar atması gerekliliğini ortaya koymuştur.

Yönetimsel anlamda yeniden yapılanma ihtiyacına yönelik hem merkezi hem de yerel yönetimin hali hazırdaki durumunu tespit etmeye ve geliştirmeye yönelik çeşitli araştırmalar ve projeler gerçekleştirilmiştir. Çalışmanın amacı kapsamında bu araştırmalardan ilki DPT (Devlet Planlama Teşkilatı), TODAİE (Türkiye ve Ortadoğu Amme İdaresi Enstitüsü) ve Maliye Bakanllğg temsilcileri tarafindan yürütülen Türk mahalli idarelerinin yeniden düzenlenmesine ilişkin yapılan araştırmadır. $\mathrm{Bu}$ araştırma kapsamında yerel yönetimlerin merkezi yönetimin vesayetinden kurtulması gerektiğine, personel eğitimine, uygulamadaki gereksiz ve sıkıcı usullerden vazgeçilmesine, merkezi ve yerel yönetimin uyumuna ve daha gelişmiş bir şehirleşme anlayışına yönelik çeşitli teklifler yer almaktadır (Yavuz, 1996, s. 1-3). İkincisi ise 1962 yllında bakanlar kurulu ile çalışmalara başlanan Merkezi Hükümet Teşkilatı Araştırma Projesi'dir. MEHTAP ile merkezi hükümet ve örgütleri arasında görev dağılımına, yerel yönetimlerin görev, yetki, mali kaynaklarına ve örgütlenmelerine yönelik önemli incelemelerde bulunulmuştur (Sakal , 2000, s. 129). Ek olarak 1960'lı yıllarda başlayıp 1970'li yılların sonuna değin I., II. ve III. kalkınma planları adı altında yerel yönetimlerin geliştirilmesine yönelik çeşitli çalışmalar yapılmışıtır.

Yerel yönetimlerin kurulduğu ilk yıllardan 1980'li yıllara kadar bilhassa bilgi iletişim teknolojilerinin gelişerek ön plana çıkmasına kadar geçen sürede yerel yönetimlerin yapısında var olan yönetim anlayışını geleneksel belediyecilik olarak adlandırmak mümkündür. Çünkü bu dönemin ilk yıllarında yerel yönetim anlayışı bazı idari görevlerden ibaretti. Merkezi vesayetin baskın olduğu yerel yönetimlerde, halk kavramı ve halka hizmet olgusu tam olarak anlaşılmamakla birlikte bürokratik yapının ağıllaştırdığı geleneksel bir yönetim anlayışının olduğu söylenebilir. Bu dönemde yapılan araştırma ve projeleri ise yönetimsel ve örgütsel anlamda görev ve sorumluluklarının yerine getirilmesini engelleyen etkenlerin çözümüne yönelik faaliyetler olarak nitelendirilebilir.

1980’li yılların sonundan itibaren yerel yönetimler ile ilgili çeşitli projeler gerçekleştirilmiştir. Araştırma kapsamında bunlardan ilki 1999-2001 yılları arasında yerel yönetimlere yönelik bir internet ağı kurmak ve bu ağın kullanılmasına yönelik eğitimleri gerçekleştirmek amacıyla YEREP (Yerel Yönetimler İçin Eğitim Malzemesi Geliştirme Projesi), 2001-2002 ylları arasında TODAİE ve YYAEM (Yerel Yönetimler Araşıtırma ve Eğitim Merkezi) kurumlarının hazırladığı proje kapsamında yerel yönetimlerin verilerinin elektronik ortama aktarılarak, bu kapsamda projeler geliştirilmesine, depolanmasına ve analize tabi tutulmas1 amaciyla YERELBİLGİ projesi olarak YERELNET projesi yerel yönetimler portalı olarak hayata geçirilmiştir (Nohutçu \& Demirel, 2005, s. 46-47). Son olarak ise 2018 yılında Türkiye il sınırlanı içerisindeki belediyelerin ortak bir platform üzerinde buluşturulmasına, bilgi ve iletişim teknolojileri alanında eksikliklerin giderilmesine, geliştirilecek olan belediyecilik yazılımlanı kapsamında vatandaş odaklı bir yerel yönetim anlayışının oluşturulması için bilgi ve iletişim teknolojilerinin etkin bir şekilde kullanılmasına zemin hazırlayan bir proje olarak E-Belediyecilik projesi hayata geçirilmiştir (İç İşleri, 2020).

Bilgi iletişim teknolojilerinin alt yapısını oluşturduğu vatandaş odaklı modern yönetim anlayışında vatandaşlar, yerel yönetim çalışanları ve yerel yönetime bağlı kuruluşlar, belediyenin ilgili paydaşlarnna 
sunduğu hizmetlere e-belediyecilik adı altında gerek e-devlet sayfasından gerekse belediyelerin ilgili sayfalarından e-belediyecilik sekmesi altında ulaşabilmektedirler. E-belediye uygulamalarının da benzer bir şekilde e-devlet uygulamaları gibi sunulmasında çeşitli yararlar vardır (Moon 2002, s. 424-431; Henden \& Henden, 2005, s. 54-59; Çoruh, 2009, s. 217-219; Şahin, 2007, s. 168);

- Daha iyi prosedür yönetimi ve ilgili kamulara daha iyi hizmet sunumu.

- Hizmetlere tek noktadan erişim.

— Yerel yönetimlerde fazla çalışan ve iş yükünün önüne geçerek. Mevcut çalışanların daha verimli iş görmesine olanak sağlar.

- Elektronik ortamda gerçekleşen işlemlerle beraber zamandan ve maliyetten tasarruf sağlamak.

— Yönetim ve kente ilişkin faaliyetlerin çok daha kolay ve pratik bir şekilde takip edilmesi ve gerçekleştirilmesi.

- Yönetim ve halk arasında iletişim güçlenerek farklı semtte ikamet eden vatandaşlara hem fiziki anlamda vatandaşların yönetime ulaşması hem de yönetim tarafindan hizmetlerin vatandaşlara çok daha hızlı bir şekilde ulaşması gibi değişkenlerin eşit düzeyde olmasına olanak sağlar.

— Halkın görüş, istek, öneri ya da şikayetlerinin yönetime daha kolay iletilmesini ve geri dönüşünün de aynı kolaylıkta olmasını sağlar.

Literatürde genel olarak e-belediye uygulaması e-devlet uygulamasinın alt grupların biri olarak kabul gördüğünden hareketle çalışmanın bundan sonraki bölümde e-devlet kavramsallaştırmasından yararlanılacak elde edilen bilgiler belediyeler açısından değerlendirilecektir.

\section{E-Devlet Kavramı ve Unsurları}

Kamu kurum ve kuruluşlarında yönetim ve hizmet noktasında "e" kavramının ön plana çıkmasında iki önemli faktör ön plana çıkmaktadır. İlki bilgi ve iletişim teknolojilerinde yaşanan gelişmelerdir. İkincisi ise özel sektörde hizmetlerin internet teknolojileri aracıllğıla sunulmasiyla; kamu yönetimindeki hizmet anlayışının doğasını da 1900’lü yıllarda hızlı bir dönüşüm sürecine sokmuştur. İletişim teknolojileri öncülügünde özel sektördeki daha iyi hizmet sunumu, daha hızlı ve daha ucuz iletişim anlayışı gibi dönüşümler vatandaşlar tarafindan kamu hizmetlerine yönelik bu yönde bir beklenti yaratmıştır (Devadoss vd., 2002, s. 253).

Bilgi ve iletişim teknolojilerinde yaşanan gelişmelerle birlikte toplumu oluşturan birey ve grupların arasındaki formel ve informel iletişim biçimleri eskiye kıyasla radikal bir değişime uğramıştır. Dolayısıyla iletişimi ve bilgiyi hizmet sunumunda temel unsur olarak kabul eden devletler, yurttaşlarıyla olan ilişkilerini yeniden gözden geçirip bunları geliştirme yoluna gitmiştir. Sunulan hizmetlerde yurttaşların dile getirdiği sorunları çözüme kavuşturan; sağladığı hizmet ve işlemlerin hızlı, kaliteli, ucuz, şeffaf, eşitlikçi ve daha güvenilir sunulmasına imkan sağlayan yeni bir yönetim modelini, elektronik devleti hayata geçirme doğrultusunda adımlar atmışlardır (Tarhan, 2010, s. 25-26).

E-Devlet yönetim modelinin literatürde farklı isimlerle kavramsallaştırıldığına rastlanmaktadır. Fountain (2001), e-devleti "sanal devlet" olarak ele alırken; Garson (2004) ise e-devleti "digital devlet" olarak değerlendirmektedir. Literatüre genel olarak bakıldığında e-devlet yaygın olarak "elektronik devlet" kavramı ile adlandırılmış ve ele alınmıştır (Howard, 2001; West, 2004; Evans \& Yen, 2006; DeBenedictis vd., 2002).

Hükümetler ve ilgili kamuları arasındaki iletişime, etkileşime ve hizmet sunumuna yeni bir bakış açısı kazandıran e-devlet modeline birdenbire ortaya çıkan bir buluş gibi yaklaşmak yanlış bir yaklaşım olacaktır. Çünkü bu model teknik ve toplumsal anlamda çeşitli gelişmeler ve bu gelişmelere paralel bir şekilde artan ihtiyaç ve beklentilere göre şekillenen bir devlet anlayışını oluşturmaktadır (İnce, 2001, s. 21). Dolayısıyla edevlet modeli ülkeye, ülkenin teknoloji kullanımına, yetkililerin teknolojiye bakış açısına, toplumsal yapıya ve tarihe göre farklılık göstermektedir. Bu farklılıklar literatürde e-devlet tanımlarına da yansımaktadır:

West (2004, s. 16) e-devleti, hükümet bilgilerinin internet gibi dijital araçlarla çevrim içi ortam da sunulması olarak tanımlayarak e-devlet modelinin bilgilendirme ağırlıklı kullanılması üzerine odaklanmıştır.

DeBenedictis ve arkadaşları (2002, s. 130) hükümet ile ilgili çok daha geniş faaliyetleri bünyesinde barındıran hükümetin verimliliğini, hesap verilebilirliği daha hızlı, etkili ve ucuz bir şekilde geliştirmek için internet ve bilgi teknolojisinin kullanıldı̆ğ, bu teknolojiler kapsamında vatandaşların ve kuruluşların 
devletin bilgi ve süreçlerine erişimini kapsayan bir sistem olarak tanımlamıştır. Yazarlar bu tanımda edevlet modelini daha geniş kapsamda değerlendirerek katulıma ve etkileşime atıfta bulunmaktadırlar.

Caldow (2001) e-devlete daha stratejik ve ileriye dönük yaklaştı̆̆ çalışmasında devletin ve vatandaşın görev ve sorumluluklarını elektronik bir sistem üzerinden yerine getirdiği, zamandan ve mekandan bağımsız, bütün süreçlerin ve kuruluşların tam entegrasyonun sağlanarak işlemlerin tek bir portal üzerinden gerçekleştirildiği bir sistem olarak tanımlayarak, e-devletin daha bütüncül ve kapsayıcı rolüne atıfta bulunmuştur.

Son olarak Mecek (2017, s. 1823) ise e-devlet modelini çok daha geniş bir kapsamda ele alarak; edevlette tüm paydaşların bilgilendirildiği, etkileşimin ve çift yönlü iletişimin sağlandığı, çevrim içi ödeme, başvuru, denetim ya da tasdik gibi işlemlerin yapıldığı, katılımı ve demokrasi kültürünü geliştiren vatandaş odaklı uygulamalar bütünü olarak tanımlamıştır.

E-devlet tanımı hem kavramsallaştırılırken hem de uygulama bağlamında yönünün ve gelişiminin belirlenmesi açısından e-devlet ve unsurları büyük önem arz etmektedir. Bu kapsamda devlet ve paydaşları amaçlarına göre şu şekilde kategorilendirilmiştir; devletten vatandaşa (G2C), devletten iş dünyasına (G2B), devletten devlete (G2G) ve devletten kamu çalışanlarınadır (G2E) (Reddick, 2004, s. 52). G2C uygulamalan devletten vatandaşa yönelik sunulan çevrimiçi hizmetlere odaklanılmaktr. G2B kapsamındaki uygulamalarda devletten iş dünyasına yönelik tedarik, bilgi toplama ve iş dünyasına dönük hizmetler yer almaktadır. G2G kategorisinde devlet ve bağlı kurumları arasındaki işlemlere yönelik yapılan faaliyetler dahil edilirken; G2E ise, devlet ve devlet çalışanlarına yönelik hizmetler ve uygulamalara karşlık gelmektedir (Tarhan, 2010, s. 39).

E-devlet kavramı anlaşıldığı üzere gelişimini ve dönüşümünü süreç içerisinde geliştiren devam ettiren bir sistem olarak değerlendirilebilir. Dolayısıyla e-devlet çok geniş bir örgütsel yapıyı ve kamusal hizmetleri barındırmaktadır. E-devletin gelişim sağlayarak dönüştüğü her dönem farklı bir boyutunu gündeme getirmektedir. Bu nedenle e-devlet modeli ele alınırken zaman içerisinde evrimsel bir süreci kapsadığı göz ardı edilmemelidir.

\section{E-Devlet Gelişim Modelleri}

Literatürde çeşitli yazarlar ve kuruluşlar tarafindan var olan durumu tespit etmek, geliştirmek ya da benzerleri ile karşılaştırmak amacıyla olgunluk modelleri adı altında çeşitli e-devlet gelişim modelleri geliştirmişlerdir (Baum ve Di Maio 2000'dan aktaran: Backus, 2001; Howard, 2001; Worldbank, 2002; United Nations, 2003; OECD, 2003; Deloitte ve Touche, 2004; Reddick, 2004; West, 2004; Andersen \& Henkriksen, 2006; Lee \& Kwak, 2012; United Nations , 2012; Janowski, 2015; Shakooh vd., 2008; Wescott, 2001; Alhomod \& Shafi , 2012; Hiller \& Belanger, 2006; Moon, 2002; Elias \& Hamid, 2007; Joshi \& Shareeful, 2018; Ronaghan, 2001; Layne \& Lee, 2001; Gottschalk, 2008) E-Devlet modelinin gelişim aşamaları, devletin etkileşimde ve iletişimde bulunduğu paydaşlarına yönelik hizmet sunumunun süreç içerisinde nasıl ve ne şekilde dönüştüğünü açıklamaktadır.

Tablo 1. E-Devlet Gelişme/Olgunluk Modelleri

\begin{tabular}{|c|c|c|c|c|c|c|}
\hline $\begin{array}{l}\text { Aşamalar } \\
\text { Yazarlar }\end{array}$ & I & II & III & IV & $\mathbf{V}$ & VI \\
\hline Backus & Bilgilendirme & Etkileşim & İşlem & Dönüşüm & & \\
\hline Howard & Yayın & Etkileşim & İşlem & & & \\
\hline Worldbank & Yayınlama & Etkileşim & İşlem & & & \\
\hline $\begin{array}{c}\text { United } \\
\text { Nation } 2003\end{array}$ & $\begin{array}{c}\text { Ortaya çıkma } \\
\text { durumu }\end{array}$ & $\begin{array}{l}\text { Gelişmişlik } \\
\text { durumu }\end{array}$ & $\begin{array}{l}\text { Etkileşim } \\
\text { durumu }\end{array}$ & $\begin{array}{l}\text { İşlemsel } \\
\text { durum }\end{array}$ & A $\breve{g}$ durumu & \\
\hline $\begin{array}{l}\text { Deloitte ve } \\
\text { Touch }\end{array}$ & $\begin{array}{l}\text { Bilgi yayınlama } \\
\text { ve yayma }\end{array}$ & $\begin{array}{l}\text { “Resmi” İki } \\
\text { yönlü işlemler }\end{array}$ & $\begin{array}{l}\text { Çok amaçlı } \\
\text { portallar }\end{array}$ & $\begin{array}{c}\text { Kişiselleştir } \\
\text { me }\end{array}$ & $\begin{array}{c}\text { Ortak } \\
\text { hizmetlerin } \\
\text { kümelenmesi }\end{array}$ & $\begin{array}{c}\text { Tam } \\
\text { entegrason } \\
\text { ve kurumsal } \\
\text { dönüşüm }\end{array}$ \\
\hline Reddick & Kataloglama & İşlem & & & & \\
\hline
\end{tabular}




\begin{tabular}{|c|c|c|c|c|c|c|}
\hline $\begin{array}{c}\text { Andersen ve } \\
\text { Henriksen }\end{array}$ & Yetiştirme & Uzant1 & Olgunluk & Düzenleme & & \\
\hline Lee ve Kwak & $\begin{array}{l}\text { Başlangıç } \\
\text { koşulları }\end{array}$ & Veri şeffaflı̆̆1 & Açık katılım & Açık iş birliği & Sürekli etkileşim & \\
\hline Janowski & Sayısallaştırma & Dönüşüm & Katılım & $\begin{array}{c}\text { Bağlamsallaş } \\
\text { tırma }\end{array}$ & & \\
\hline $\begin{array}{c}\text { Shahkooh } \\
\text { vd. }\end{array}$ & $\begin{array}{c}\text { Çevrimiçi } \\
\text { varlık }\end{array}$ & Etkileşim & İşlem & $\begin{array}{c}\text { Dijital } \\
\text { demokrasi }\end{array}$ & & \\
\hline Wescot & $\begin{array}{c}\text { Dahili bir e- } \\
\text { posta kurma } \\
\text { sistemi }\end{array}$ & $\begin{array}{l}\text { İki yönlü } \\
\text { iletişime izin } \\
\text { vermek }\end{array}$ & $\begin{array}{c}\text { Değer } \\
\text { erişimine izin } \\
\text { vermek }\end{array}$ & $\begin{array}{l}\text { Birleşik } \\
\text { hükümet }\end{array}$ & & \\
\hline $\begin{array}{c}\text { Alhomod ve } \\
\text { Shafi }\end{array}$ & $\begin{array}{l}\text { Internette var } \\
\text { olmak }\end{array}$ & $\begin{array}{c}\text { Vatandaş ve } \\
\text { hükümet } \\
\text { arasinda } \\
\text { etkileşim }\end{array}$ & $\begin{array}{l}\text { Web üzerinde } \\
\text { işlem }\end{array}$ & $\begin{array}{c}\text { Hizmetlerin } \\
\text { entegrasyon } \\
\mathrm{u}\end{array}$ & & \\
\hline $\begin{array}{c}\text { Hiller } \\
\text { Belanger }\end{array}$ & $\begin{array}{l}\text { Bilgi/Bilgilendi } \\
\text { rme }\end{array}$ & $\begin{array}{l}\text { İki yönlü } \\
\text { iletişim }\end{array}$ & İşlem & Entegrasyon & Katılım & \\
\hline Moon & $\begin{array}{l}\text { Basit bilgi } \\
\text { yayma }\end{array}$ & $\begin{array}{l}\text { İki yönlü } \\
\text { iletişim }\end{array}$ & $\begin{array}{c}\text { Hizmet ve } \\
\text { finansal } \\
\text { işlemler }\end{array}$ & Entegrasyon & Siyasal katılım & \\
\hline $\begin{array}{c}\text { Elias ve } \\
\text { Hamid }\end{array}$ & Kataloglama & Etkileşim & İletişim & Etkileşim & Entegrasyon & \\
\hline $\begin{array}{l}\text { Joshi ve } \\
\text { Shareeful }\end{array}$ & $\begin{array}{c}\text { Temel } \\
\text { hizmetler }\end{array}$ & $\begin{array}{c}\text { Elverişli } \\
\text { hizmetler }\end{array}$ & $\begin{array}{c}\text { İşlem } \\
\text { hizmetleri }\end{array}$ & $\begin{array}{c}\text { Hizmetler } \\
\text { otomasyonu }\end{array}$ & & \\
\hline Layne ve Lee & Kataloglama & İşlem & $\begin{array}{c}\text { Dikey } \\
\text { Entegrasyon }\end{array}$ & $\begin{array}{c}\text { Yatay } \\
\text { Entegrasyon }\end{array}$ & & \\
\hline Ronaghan & Gelişen & Geliştirilmiş & Etkileşimli & Sorunsuz & & \\
\hline Gottschalk & $\begin{array}{c}\text { Bilgisayarların } \\
\text { birlikte } \\
\text { çalışabilirliği }\end{array}$ & $\begin{array}{l}\text { Süreç birlikte } \\
\text { çalışabilirliği }\end{array}$ & $\begin{array}{l}\text { Bilgi birlikte } \\
\text { çalışabilirliği }\end{array}$ & $\begin{array}{c}\text { Birlikte } \\
\text { çalışabilirlik } \\
\text { değeri }\end{array}$ & $\begin{array}{l}\text { Hedef birlikte } \\
\text { çalışabilirlik }\end{array}$ & \\
\hline
\end{tabular}

E-Devlet gelişme aşamaları farklı yazarlar tarafindan farklı şekillerde ele alındığı görülmektedir. Literatürde farklı yazarlarca dile getirilen çok sayıda gelişme aşamaları bulunmaktadır. E-devlet gelişme aşamaları sayıca çok olsa bile arka planda e-devletin gelişim sürecine yönelik ifade ettiği bulgular ortak bir tablo oluşturmaktadır. Tablo incelendiğinde e-devlet gelişim modelini temelde dört aşamada belirtmek mümkündür. İlk aşamasında devletin elektronik ortamda "bilgilendirme" amacıyla açtığ bir web sitesi kullanıcılara yönelik hizmet vermektedir. İkinci aşamasında ise hükümetler interneti daha sık kullanmaya başlamıştır. Bu aşamada vatandaşlar e-posta yolu ile devlet kurumlarına soru sorma imkanını elde ederek "etkileşim" fırsatını yakalamışlar ve çeşitli formları indirebilmişlerdir. Üçüncü aşamasında ise ilgili kamu kuruluşuna gitmeksizin elektronik ortamda "işlem" yapabilme imkanı ön plana çıkmaktadır. Dördüncü ve son aşamasında ise kamu kurumları birbirine entegre bir şekilde işlemlerin tek portal üzerinden "bütünleşme" durumunu ifade etmektedir. Bunların dışında (Lee \& Kwak, 2012; Janowski, 2015; Joshi \& Shareeful, 2018; Gottschalk, 2008) -devlet gelişim modellerini genel dağllımın dışında ismen farklı şekilde ele aldığ1 görülmektedir.

Elektronik bir devletin gelişmişlik modeli, uzun vadede hükümetlerin örgütsel anlamda çabalarını değerlendirmede ve e-devlet faaliyetlerinin izlenmesinde önemli bir rol oynamaktadır (Andersen \& Henkriksen, 2006, s. 237; Siau \& Yuan, 2005, s. 243) Bu nedenle e-devlet gelişim modeli örgütsel anlamda var olan durumu tespit etmede, ileriye dönük stratejiler geliştirmede ve diğer benzerleriyle karşlaştırma yapmak açısından bu durum, hükümetler açısından için önem arz etmektedir.

Bu çalışmada e-devlet gelişim aşamalarına yönelik genel kanı göz önünde bulundurularak bilgilendirme, etkileşim, işlem ve bütünleşme aşamalanı adı altında e-devlet gelişim aşamaları açıklanacaktır.

\subsection{Bilgilendirme}

İlk aşama olan bilgilendirme aşaması en net ve en genel tanımıyla devletin elektronik ortamda var olarak, dış hedef gruplara (G2C ve G2B) ilgili bilgilerin ulaştırılmasıdır (Baum ve Di Maio 2000'den aktaran: Backus, 2001, s. 5). Bu aşamada oluşturulan web siteler üstlendikleri görev itibari ile telefon 
trafiğini azaltan elektronik bir ansiklopediye benzetilmektedir (Deloitte ve Touche, 2004, s. 22). Bilgilerin elektronik ortamda sunulmaya başlanmasıyla maddi açıdan tasarruf sağlandığı ve çalışanların iş yükünün azaltıldığı söylenebilir (Reddick, 2004, s. 53; Layne \& Lee, 2001, s. 126). Son olarak bilgilendirme aşamasında vatandaşlar bilgileri okumaktan başka herhangi bir işlem yapmadıkları için devlet ve paydaşlan arasında sınırlı bir etkileşim söz konusudur (West, 2004, s. 17). Bu aşamada devlete ait kurumların web sitelerinin vatandaşları başvuru işlemleri ile bu süreçte gerekli olan belgelerin edinilmesi için yönlendirme amacıyla kullanıldığı söylenebilir. Vatandaşlar web sitesinde yer alan bilgiler doğrultusunda nereye, kime, nasıl ve hangi belgelerle başvuracakları konusunda bilgi edinebilirler.

\subsection{Etkileşim}

Bu aşamada intranet daha kapsamlı kullanılmaya başlanmıştır (Andersen \& Henkriksen, 2006, s. 243). Çünkü ilk aşamada çevrim içi bilgilendirme amacıyla kullanılan web siteleri bu aşamada vatandaşın hükümete e-posta yolu ile soru sorup bilgi almasına imkan sağlamaktadır (Howard, 2001, s. 7). Etkileşim aşaması devlet ve vatandaş arasında var olan etkileşim ve iletişimin değişmesinden dolayı devrimci bir varlık olarak nitelendirilen e-devletin başlangıcıdır (Layne \& Lee, 2001, s. 129). Etkileşim aşamasında vatandaşlar devlete soru sorabilir, çeşitli form ve belgeleri indirebilir. Bu aşamada devlet ve vatandaş arasındaki iletişim ve etkileşim e-devlet sayesinde tek yönlü bir süreçten iki yönlü iletişim sürecine evrilerek; bu sürece vatandaşın tam anlamıyla dahil olmasının başlangıcı olarak da nitelendirilebilir. Bu gelişmeyle birlikte vatandaşlar daha aktif bir rol üstlenmesi mümkün hale gelmiştir. Vatandaşların devlet kurumlarıyla iletişimlerini geliştirmesi yanında kendilerini ifade edebilecekleri bir ortamın sağlanmasıyla birlikte demokrasinin gelişmesi için de önemli bir adım olarak değerlendirilebilir. Bunun yanında gelir vergisi beyannamesi gibi birtakım belgelere erişim sağlama bunlanı elektronik ortamda doldurarak yazdırabilmekte böylece kamu kurumlarına gitmek durumunda kaldığı hallerde gereksiz zaman kayıplarının önüne geçilebilmektedir.

\section{3. İşlem}

E-devletin devrimsel nitelikte bir diğer aşaması da işlem aşamasıdır. Bu aşamada vatandaşlar (G2C) ve işletmeler (G2B) çeşitli belgelerin doldurulmasından ödeme ve başvurularını elektronik ortamda (Baum ve Di Maio 200'den aktaran: Backus, 2001, s. 6) yüz yüze başvuruya gerek kalmadan çevrimiçi olarak gerçekleştirebilmektedirler. Bu nedenle etkileşim aşamasında sadece soru-cevap kapsamında bir diyalog söz konusu isen; işlem aşamasında hükümet dahilinde ve diş ilişkilerinde de bir dönüşüm yaşanmıştır (Janowski, 2015, s. 225). Vatandaşların devletle olan işlerinde sadece formaliteleri gerçekleştirmek için ilgili kamu kurumuna gitme gereksinimini ortadan kaldıran bu aşama ile hem kamu kurumları hem de vatandaşlar açısından işlemlerin zamana ve mekana bağlılı̆̆1 ortadan kaldırılmış daha öncesinde hem hizmet sunan kamu kuruluşları hem de hizmet alan vatandaşlar tarafindan dile getirilen birtakım olumsuzluklara çözüm üretebilmek için umut olmuştur.

\subsection{Bütünleşme}

$\mathrm{Bu}$ aşamada devlet kurumları birbiri arasında entegre edilerek ilgili paydaşlar için ana elektronik devlet portalı oluşturulmaktadır (Elias \& Hamid, 2007, s. 24). E-devlet gelişim sürecinin başlangıcında elektronik ansiklopediye benzetilen e-devlet, bu aşamada her vatandaşı ihtiyacına ve beklentisine göre şekillendirilen ve kişiselleştirilmiş, bütünleşik hizmetler aşamasını ifade etmektedir (Deloitte ve Touche, 2004, s. 24). Yani bu aşamada vatandaşlann hangi departmanda olduğunu bilmeden hizmete erişmesidir. Burada hizmet almak için ziyaret edilecek noktalar, departmanlar değil hizmetlerdir (Caldow, 2001, s. 3). Bütünleşme aşamasıyla vatandaşlar artık var olan bütün hizmetleri zaman, mekan ya da farklı bir adres zorunluluğu olmadan tek bir portal üzerinden gerçekleştirebileceklerdir. Bu durum, aynı hizmetin birden fazla platform üzerinden sunulmasından kaynaklanan kafa karışıklı̆̆ını ortadan kaldırması bakımından önemlidir. Diğer yandan bu hizmetlerin tek bir portaldan sunulması vatandaşın e-devlet hizmetlerinden yararlanırken güvenilirlik noktasında yaşayabilecekleri ikilemlere son verilmesine katkı sağlayabilir. Güvenlik kayg1sı ile alabilecekleri pek çok hizmette kuruma bizzat gitmeyi tercih eden vatandaşların tercihlerini e-devlet platformundan yana kullanmalarına motivasyon sağlayabilir. 
Tablo 2. E-Devlet Gelişim Aşamaları ve Etkileşim Alanlarına Yönelik Çözümler

\begin{tabular}{|c|c|c|c|}
\hline $\begin{array}{c}\text { Gelişim } \\
\text { aşamalanı }\end{array}$ & D1ş hedef gruplara yönelik G2C & $\begin{array}{c}\text { D1ş hedef gruplara } \\
\text { yönelik G2B }\end{array}$ & $\begin{array}{c}\text { İç hedef gruplara } \\
\text { yönelik G2G }\end{array}$ \\
\hline $\begin{array}{l}\text { Bilgilendirme } \\
\text { Aşaması }\end{array}$ & $\begin{array}{l}\text { Yerel, kurumlar hakkında ve ulusal } \\
\text { anlamda bilgilendirme: Adresler, } \\
\text { açılışlar, çalışanlar, ilgili telefon } \\
\text { numaraları, yasa, kural ve düzenlemeler, } \\
\text { duyuru ve haberler gibi } \\
\text { bilgilendirmeleri içerir. }\end{array}$ & $\begin{array}{l}\text { Ticari anlamda bilgiler, } \\
\text { açllşs saatleri, çalışanlar } \\
\text { ve ulaşım bilgileri, kanun, } \\
\text { kural ve düzenlemeler }\end{array}$ & $\begin{array}{l}\text { Bilgilendirme amaçlı } \\
\text { durağan bir intranet } \\
\text { Bilgi Yönetimi (LAN) }\end{array}$ \\
\hline $\begin{array}{l}\text { Etkileşim } \\
\text { Aşaması }\end{array}$ & $\begin{array}{l}\text { Web sitesi üzerinden formları indirme } \\
\text { ve gönderme } \\
\text { Form doldurmaya yönelik çevrim içi } \\
\text { yardım (Doğum, ölüm, izin ve sertifika) } \\
\text { E-Posta ile bildirim, Bültenler ve } \\
\text { Tartışma grupları } \\
\text { Anketler ve kişiselleştirilmiş web siteleri }\end{array}$ & $\begin{array}{l}\text { Formları indirme ve web } \\
\text { sitelerine form } \\
\text { gönderebilme ve } \\
\text { doldurmaya yönelik } \\
\text { çevrim içi yardım } \\
\text { (İzinler) } \\
\text { E-Posta bildirimi }\end{array}$ & $\begin{array}{c}\text { E-Posta } \\
\text { Etkileşimli bilgi } \\
\text { veritabanları } \\
\text { Şikayet işleme araçları }\end{array}$ \\
\hline İşlem Aşaması & $\begin{array}{l}\text { Lisans başvuruları ve yenilemeleri, } \\
\text { kişisel hesaplarla çeşitli ödemeler, } \\
\text { çevrim içi kayıt ve oylama işlemleri. }\end{array}$ & $\begin{array}{l}\text { Web sitesi aracıllğıyla } \\
\text { lisans başvuru ve } \\
\text { yenileme isslemleri, } \\
\text { tedarik süreçlerine } \\
\text { katıllım ve çeşitli } \\
\text { ödemeler }\end{array}$ & $\begin{array}{l}\text { Kamu kurumları } \\
\text { arasında işlemler }\end{array}$ \\
\hline $\begin{array}{l}\text { Dönüşüm } \\
\text { Aşaması }\end{array}$ & $\begin{array}{c}\text { Bütün hizmetlerin bir portalda entegre } \\
\text { olduğu kişisel hesaplara sahip, } \\
\text { kişiselleştirilmiş web sitesi }\end{array}$ & $\begin{array}{l}\text { Bütün hizmetlerin bir } \\
\text { portalda entegre olduğu } \\
\text { ticari hesaplara sahip, } \\
\text { ișletme hesapları }\end{array}$ & $\begin{array}{c}\text { Veri tabanı } \\
\text { entegrasyonu }\end{array}$ \\
\hline
\end{tabular}

Backus, M. (2001). E-Govarnance and developing countries: introduction and examples. IICD.

Elektronik devletin gelişim adımları ile bu aşamalarda etkileşim içerisinde bulunduğu hedef gruplara hangi hizmetlerin sağlandığına ilişkin bir sınıflamanın yapılması konunun bütüncül bir yaklaşımla değerlendirilmesi bakımından önem taşımaktadır. Tablo 2'de e-devlet gelişim aşamalarına ve bu aşamalarda hangi uygulamaların yer aldığı bütüncül bir bakış açısı ile sunulmaktadır

Tabloya bakıldığında "bilgilendirme aşaması" kapsamında dış hedef gruplar olarak değerlendirilebilen vatandaşlar (G2C) ve iş dünyasına (G2B) yönelik uygulamalar ile iç hedef kitle olarak tanımlanabilen diğer kamu kurumlarına (G2G) yöneltilen içerikler farklılaştığı görülmektedir. Bilgilendirme aşaması için ortaya çıkan bu farklılaşmanın "etkileşim aşaması", "işlem aşaması" ve "dönüşüm aşaması" için de geçerli olduğu görülmektedir.

Devlet hizmetlerinin sunulmasında önemli bir firsat sunan e-devlet uygulamaları değerlendirilirken daha çok merkezi yönetim üzerinden değerlendirmelerin yapıldığ1 görülmektedir. Halbuki merkezi yönetimin hizmetlerini başarılı bir biçimde planlaması ve hayata geçirmesi hizmet sunduğu paydaşlara ne kadar yakın olduğuyla ve onların istek ve beklentilerine ne kadar kulak verdiğiyle ilgilidir.

\section{Metodoloji}

Araştırmanın evrenini 81 il belediyesi oluştururken (www.tbb.gov.tr, 2020) örneklemini ise 30 büyükşehir belediyesi oluşturmaktadır. Çalışmada büyükşehir belediyelerinin kurumsal web sayfalarında ve e-devlet platformu üzerinden paydaşlarına hangi belediye hizmetlerini, nasıl sundukları sorgulanmaktadır. Araştırma Türkiye'de faaliyet gösteren 30 büyükşehir belediyesinin kurumsal web sayfaları ve e-devlet platformu üzerinden sunduğu hizmetler 02-08 Aralık 2020 tarihleri arasında içerik analizi yöntemi kullanılarak değerlendirilmiştir. Sözel, yazılı ya da diğer materyallerin içerdiği mesajları anlam veya dilbilgisi açısından nesnel ve sistematik bakımdan sınıflandırma, sayılara dönüş̧ürme ve çıkarımda bulunma yoluyla sosyal gerçeği ortaya çıkmayı amaçlayan (Tavşancıl \& Arslan, 2001, s. 22) içerik analizinin web sitelerin incelenmesine ilişkin çalışmalarda ağırlıklı olarak kullanıldığı görülmektedir (Esrock ve Leichty 2000 ve Kamat 2002'den aktaran: Tarhan, 2007, s. 84). 
Tablo 3. Büyükşehir Belediyeleri ve Kurumsal Web Site Adresleri

\begin{tabular}{|l|l|}
\hline Büyükşehir Belediyeleri & Kurumsal Web Sayfası Adresleri \\
\hline 1. Ankara BB & www.ankara.bel.tr \\
\hline 2. Adana BB & www.adana.bel.tr \\
\hline 3. Antalya BB & www.antalya.bel.tr \\
\hline 4. Aydın BB & https://.aydin.bel.tr \\
\hline 5. Balıkesir BB & www.balikesir.bel.tr \\
\hline 6. Bursa BB & www.bursa.bel.tr \\
\hline 7. Denizli BB & www.denizli.bel.tr \\
\hline 8. Diyarbakr BB & www.diyarbakir.bel.tr \\
\hline 9. Erzurum BB & www.erzurum.bel.tr \\
\hline 10. Eskişehir BB & www.eskisehir.bel.tr \\
\hline 11. Gaziantep BB & www.gaziantep.bel.tr \\
\hline 12. Hatay BB & www.hatay.bel.tr \\
\hline 13. İstanbul BB & https://www.ibb.istanbul \\
\hline 14. İzmir BB & www.izmir.bel.tr \\
\hline 15. Kahramanmaraş BB & https://kahramanmaras.bel.tr \\
\hline 16. Kayseri BB & www.kayseri.bel.tr \\
\hline 17. Kocaeli BB & www.kocaeli.bel.tr \\
\hline 18. Konya BB & www.konya.bel.tr \\
\hline 19. Malatya BB & www.malatya.bel.tr \\
\hline 20. Manisa BB & www.manisa.bel.tr \\
\hline 21. Mardin BB & www.mardin.bel.tr \\
\hline 22. Muğla BB & www.mugla.bel.tr \\
\hline 23. Mersin BB & www.mersin.bel.tr \\
\hline 24. Ordu BB & www.ordu.bel.tr \\
\hline 25. Sakarya BB & www.sakarya.bel.tr \\
\hline 26. Samsun BB & www.samsun.bel.tr \\
\hline 27. Şanlıurfa BB & www.sanliurfa.bel.tr \\
\hline 28. Tekirdağ BB & http://www.tekirdag.bel.tr/ \\
\hline 29. Trabzon BB & www.trabzon.bel.tr \\
\hline 30. Van BB & https://van.bel.tr/ \\
\hline & \\
\hline
\end{tabular}

Araştırmada kodlama cetvelinin oluşturulmasında Sayımer'in (2015) çalışmasında kullanmış olduğu kodlama cetvellerinden yararlanılarak çalışmaya uygun bir şekilde yeni kategoriler eklenmiştir. Analizlerde öncelikle ülkemizde faaliyet gösteren büyükşehir belediyelerini www.belediyeler.gov.tr platformuna üye olup olmadıklannı, kurumsal web sayfalarında paydaşlanına yönelik bu hizmetleri hangi isimle sundukları, kurumsal web sayfalarından ve e-devlet platformu üzerinden sundukları hizmetlerin oranı, bu hizmetlerin e-devlet olgunlaşma modelinde yer alan aşamalardan bilgilendirme, etkileşim ve işlem aşamalarına göre dağılımlarının ne olduğu ve sunulan hizmetlerin paydaşlara göre nasıl dağılım gösterdiği incelenmiştir. İçerik analizi kapsamında kodlama cetveli oluşturulurken ortaya konan başlıca kategoriler;

- Bilgilendirme: Büyükşehir belediyelerinin paydaşlarını herhangi bir konu hakkında bilgilendirmek amacıyla sunmuş olduğu hizmetlerdir.

— Etkileşim: Büyükşsehir belediyelerinin paydaşlarından gelen istek, öneri, şikayetlerini iletebilmelerine imkan sağlayan ve onlarla karşılıklı diyalog ortamı oluşturan uygulamalardır.

— İşlem: Büyükşehir belediyelerinin paydaşlarının kuruma gelmeden herhangi bir konu ile ilgili işlemlerini çevrimiçi olarak gerçekleştirebildiği hizmetlerdir.

— Bütünleşme: Büyükşehir belediyelerinin web sayfalarında sundukları hizmetlerin e-devlet platformu ile bütünleşik olarak tek duraktan sunulmasıdır.

— Devletten Vatandaşa (G2C): Büyükşehir belediyelerinin vatandaşlarına yönelik sunmuş olduğu ebelediye hizmetleridir.

— Devletten İş Dünyasına Yönelik (G2B): Büyükşehir belediyelerinin paydaşlarından biri olan iş dünyasına yönelik vermiş olduğu e-belediye hizmetleridir. 
— Devletten Devlete (G2G): Büyükșehir belediyelerinin iletișim ve etkileșim içerisinde bulundukları/bulunacakları diğer kamu kurumlarına yönelik vermiş olduğu e-belediye hizmetleridir.

- Devletten-Kamu Çalışanlanna (G2E): Büyükşehir belediyelerinin kendi bünyesinde ve dışındakilere yönelik sunmuş olduğu e-belediye hizmetleridir.

$\mathrm{Bu}$ işlevsel tanımlar çerçevesinde araştırmanın geçerlilik ve güvenirliliğini sağlamak amacıyla "güvenilirlik=uzlaşma sayısı \uzlaşma+uzlaşma sayısı" formülü (Miles \& Huberman, 1994, s. 64) kullanılmıstır ve birbiri ile örtüşen kategoriler, bulgular kapsamında ele alınmıştır.

Araştırma e-devlet hizmeti sunan büyükşehir belediyeleri ile sınırlıdır. Araştırmadaki bir başka sınıllılı ise belediyelerin kurumsal web sayfalarında yer alan (iki belediye hariç) e-belediye uygulamaları ile sınırlıdır. Araştırmadaki diğer sınırlılık ise e-devlet platformu üzerinden ilgili belediyelerin tüm kullanıcılara açı olan e-devlet uygulamaları ile sinırlıdır.

Araştırma kapsamında cevabı aranacak başlıca sorular şöyledir: katılmıștır?

Araştırma sorusu 1: İçişleri Bakanlı̆̆ının e-belediye platformuna kaç büyükşehir belediyesi sunmaktadır?

Araşttrma sorusu 2: Büyükşehir belediyeler kurumsal web sayfalarından bu hizmetleri hangi isimle Araștrma sorusu 3: Büyükşehir belediyelerinin kurumsal web sayfalarından ve e-devlet platformu üzerinden sunmuş oldukları e-hizmetlerin dağllımı nasıldır?

Araştırma sorusu 4: Büyükşehir belediyelerinin kurumsal web sayfalarında sundukları ehizmetlerinin bilgilendirme, etkileşim ve işlem kapsamındaki dağılımı nasıldır?

Araștırma sorusu 5: Büyükşehir belediyelerinin e-devlet platformu üzerinden sundukları ehizmetlerin bilgilendirme, etkileşim ve işlem kapsamındaki dağılımı nasıldır?

Araştırma sorusu 6: Büyükşehir belediyelerinin etkileşim içerisinde bulunduğu paydaşlarına sunmuş olduğu e-hizmetlerin dağglımı nasıldır?

\section{Bulgular}

Örneklem kapsamında ele alınan 30 büyükşehir belediyesinden 18'inin (\%60) www.beledive.gov.tr adresine kayıtlı olduğu bulgulanmıştır. Bu belediyeler, Adana Büyükşehir Belediyesi, Antalya Büyükşehir Belediyesi, Balıkesir Büyükşehir Belediyesi, Denizli Büyükşehir Belediyesi, Diyarbakır Büyükşehir Belediyesi, Erzurum Büyükşehir Belediyesi, Eskişehir Büyükşehir Belediyesi, Gaziantep Büyükşehir Belediyesi, Kahramanmaraş Büyükşehir Belediyesi, Konya Büyükşehir Belediyesi, Malatya Büyükşehir Belediyesi, Manisa Büyükşehir Belediyesi, Mardin Büyükşehir Belediyesi, Mersin Büyüksşehir Belediyesi, Sakarya Büyükşehir Belediyesi, Samsun Büyükşehir Belediyesi, Trabzon Büyükşehir Belediyesi ve Van Büyükşsehir Belediyesi olarak görülmektedir.

Tablo 4. E-Belediye Portalına Üye Belediyelerin Görünümü

\begin{tabular}{|l|c|}
\hline Belediyeler & $\begin{array}{c}\text { belediyeler.gov.tr } \\
\text { platformuna } \\
\text { üyelik }\end{array}$ \\
\hline 1. Ankara BB & Yok \\
\hline 2. Adana BB & Var \\
\hline 3. Antalya BB & Var \\
\hline 4. Aydın BB & Yok \\
\hline 5. Balıkesir BB & Var \\
\hline 6. Bursa BB & Yok \\
\hline 7. Denizli BB & Var \\
\hline 8. Diyarbakar BB & Var \\
\hline 9. Erzurum BB & Var \\
\hline 10. Eskişehir BB & Var \\
\hline 11. Gaziantep BB & Var \\
\hline 12. Hatay BB & Yok \\
\hline 13. İstanbul BB & Yok \\
\hline 14. İzmir BB & Yok \\
\hline
\end{tabular}




\begin{tabular}{|l|c|}
\hline 15. Kahramanmaraş BB & Var \\
\hline 16. Kayseri BB & Yok \\
\hline 17. Kocaeli BB & Yok \\
\hline 18. Konya BB & Var \\
\hline 19. Malatya BB & Var \\
\hline 20. Manisa BB & Var \\
\hline 21. Mardin BB & Var \\
\hline 22. Muğla BB & Yok \\
\hline 23. Mersin BB & Var \\
\hline 24. Ordu BB & Yok \\
\hline 25. Sakarya BB & Var \\
\hline 26. Samsun BB & Var \\
\hline 27. Şanliurfa BB & Yok \\
\hline 28. Tekirdağ BB & Yok \\
\hline 29. Trabzon BB & Var \\
\hline 30. Van BB & Var \\
\hline Toplam: 30 & Katılan saysı: 18 \\
\hline
\end{tabular}

İç İşleri Bakanlığı'nın kurumsal web sayfası içerişinde bulunan bu platforma her ne kadar belediyelerin yarısından fazlası (18; \%60) katılmış olsa da vatandaşların bilgi edinme, etkileşim ve işlem faaliyetlerini güvenilir bir biçimde gerçekleştirmeleri için diğer belediyelerinde üye olmaları büyük önem arz etmektedir. Belediye hizmetlerini e-devlet hizmetleriyle çevrimiçi olarak gerçekleştirmede belediye hizmetlerinin yöneltildiği paydaşların bir bölümünün toplumda konuşulan ve zaman zaman medyaya yansıyan siber suçlara ilişkin haberlerden dolayı çok istekli olmadıkları ve bizzat kuruma gitmeyi tercih ettikleri görülmektedir.

Tablo 5. Büyükşehir belediyelerinin E-Belediye ve E-Devlet Portalı Üzerinden Sunduğu Hizmetlerin Analizi

\begin{tabular}{|l|l|c|c|}
\hline Belediyeler & Adlandırma & $\begin{array}{c}\text { E-Belediye } \\
\text { uygulama } \\
\text { sayıs1 }\end{array}$ & $\begin{array}{c}\text { E-Devlet } \\
\text { uygulama } \\
\text { sayıs1 }\end{array}$ \\
\hline 1. Ankara BB & E-Ankara Uygulamaları & 22 & 5 \\
\hline 2. Adana BB & E-Belediye Uygulamaları & 7 & 4 \\
\hline 3. Antalya BB & E-Belediye & 21 & 7 \\
\hline 4. Aydın BB & Online İşlemler & 11 & 4 \\
\hline 5. Balıkesir BB & E-Belediye & 20 & 3 \\
\hline 6. Bursa BB & E-Belediye & 29 & 10 \\
\hline 7. Denizli BB & E-Belediye & 19 & 12 \\
\hline 8. Diyarbakır BB & E-Belediye & 16 & 8 \\
\hline 9. Erzurum BB & Yok & 10 & 4 \\
\hline 10. Eskişehir BB & E-Belediye-Bilgi Edinme & 17 & 3 \\
\hline 11. Gaziantep BB & E-Belediye & 19 & 4 \\
\hline 12. Hatay BB & E-Belediye Sistemi & 10 & 4 \\
\hline 13. İstanbul BB & E-Belediye Uygulamaları & 40 & 8 \\
\hline 14. İzmir BB & E-İşlem Merkezi & 31 & 1 \\
\hline 15. Kahramanmaraş BB & E-Belediye & 19 & 5 \\
\hline 16. Kayseri BB & E-Belediye & 14 & 6 \\
\hline 17. Kocaeli BB & E-Belediye & 18 & 10 \\
\hline 18. Konya BB & E-Belediye-İnteraktif & 35 & 9 \\
\hline 19. Malatya BB & E-Belediye & 28 & 10 \\
\hline 20. Manisa BB & E-Belediye & 10 & 7 \\
\hline 21. Mardin BB & Yok & 9 & 4 \\
\hline 22. Muğla BB & E-Belediye & 16 & 2 \\
\hline 23. Mersin BB & E-Belediye Hizmetleri & 16 & 7 \\
\hline 24. Ordu BB & Online İşlemler- Borç & 17 & 3 \\
\hline 25. Sakarya BB & Ödeme & 20 & 8 \\
\hline 26. Samsun BB & E-Belediye Hizmetleri & 13 & 4 \\
\hline & E-Belediye-Online İşlemler & & \\
\hline & & & \\
\hline
\end{tabular}




\begin{tabular}{|l|l|c|c|}
\hline 27. Şanluurfa BB & E-Belediye & 15 & 6 \\
\hline 28. Tekirdağ BB & $\begin{array}{l}\text { E-Hizmet - E-Platformlar - } \\
\text { Çevrimiçi Hizmetler }\end{array}$ & 27 & 17 \\
\hline 29. Trabzon BB & E-Belediye & 15 & 4 \\
\hline 30. Van BB & E-Belediye & 13 & 5 \\
\hline \multicolumn{2}{l}{ Toplam: } & $\mathbf{5 5 7}$ & $\mathbf{1 8 4}$ \\
\hline
\end{tabular}

Araştırma kapsamında incelenen belediyelerin kurumsal web sayfalarında e-belediye hizmetlerine hangi adla yer verdikleri de sorgulanmıştır. Bu belediyelerden 28’i kurumsal web sayfalarından sunmuş oldukları e-belediye hizmetlerini bir başlık altında tanımlarken; 2 belediyenin ise (Erzurum BB ve Mardin BB) bu hizmetleri herhangi bir başlık altında toplamadığ1 görülmüștür. Buna göre incelenen belediyelerden 15’i "e-belediye" 3’ü "e-belediye uygulamaları" ve 2'si "e-belediye hizmetleri”" olarak adlandırmışlardır. Diğer belediyeler ise "e-belediye sistemi", "e-belediye-bilgi edinme", "e-belediye-interaktif", "e-belediye-online işlemler", "e-işlem merkezi", "e-hizmet, e-platformlar- çevrimiçi hizmetler", "online işlemler" ve "online işlemler-borç ödeme" işlemleri olarak adlandırmıştır.

Büyükşehir belediyelerinin kurumsal web sayfalarında vatandaşlarına dönük 557 hizmete yer verdiği görülmektedir. Belediyelerden İstanbul Büyükșehir Belediyesi (40; \%7.18), Konya Büyükşehir Belediyesi (35; \%6.28) Bursa Büyükşehir Belediyesi (29; \%5.20) en fazla hizmete yer verirken; Manisa Büyükşehir Belediyesi, Hatay Büyükşehir Belediyesi, Erzurum Büyükşehir Belediyesi (10; \%1,79), Mardin Büyükşehir Belediyesi $(9 ; \% 1,61)$ ve Adana Büyükşehir Belediyesi (7; \%1.25) en az hizmet veren belediyeler olduğu görülmektedir. Buradan hareketle İstanbul Büyükşehir Belediye'si, Konya Büyükşehir Belediye'si ve Bursa Büyükşehir Belediye'si e-belediye uygulamalarını kurumsal web sayfalarında daha aktif bir biçimde vatandaşlarına sundukları söylenebilir. Buna karşın Erzurum Büyükşehir Belediyesi, Hatay Büyükşehir Belediyesi, Manisa Büyükşehir Belediyesi, Mardin Büyükşehir Belediyesi ve Adana Büyükşehir Belediye'lerinin ise kurumsal web sayfalarında e-belediyecilik uygulamalarını vatandaşlarına sunmada ebelediye uygulamalarından yeterince yararlanmadığı görülmektedir.

Belediyelerin e-devlet platformu üzerinden sundukları hizmetlerin sayısı toplamda 184'tür. Bunlardan Tekirdağ Büyükşsehir Belediyesi (17; \%9.23), Denizli Büyükşehir Belediyesi (12; \%6.52), Bursa Büyükşehir Belediyesi, Kocaeli Büyükşehir Belediyesi ve Malatya Büyükşehir Belediyesi (10; \%5.43) en fazla hizmete yer verilen 3 belediye iken; Ordu Büyükşehir Belediyesi, Eskişehir Belediyesi ve Balıkesir Büyükşehir Belediyesi (3; \%1.63) Muğla Büyükşehir Belediyesi (2; \%1.08) İzmir Büyükşehir Belediyesi (1; \%0.54) ise edevlet platformu üzerinden en az hizmet sunan belediyeler olarak dikkat çekmektedir.

Tablo 6. Büyükşehir Belediyelerin İlgili Paydaşlarına Yönelik E-Hizmetlerin Analizi

\begin{tabular}{|c|c|c|c|c|}
\hline BELEDİYELER & $\begin{array}{c}\text { Devletten- } \\
\text { Vatandaşlara } \\
\text { (G2C) }\end{array}$ & $\begin{array}{c}\text { Devletten-İş } \\
\text { Dünyasına } \\
\text { (G2B) }\end{array}$ & $\begin{array}{l}\text { Devletten- } \\
\text { Devlete } \\
\text { (G2G) }\end{array}$ & $\begin{array}{c}\text { Devletten-Kamu } \\
\text { Çalışanlanına } \\
\text { (G2E) }\end{array}$ \\
\hline 1. Ankara BB & Var & Var & Var & Var \\
\hline 2. Adana BB & Var & Var & Var & Var \\
\hline 3. Antalya BB & Var & Var & Var & Var \\
\hline 4. Aydin BB & Var & Var & Var & Var \\
\hline 5. Balıkesir BB & Var & Var & Var & Var \\
\hline 6. Bursa BB & Var & Var & Var & Var \\
\hline 7. Denizli BB & Var & Var & Var & Var \\
\hline 8. Diyarbakır BB & Var & Var & Var & Var \\
\hline 9. Erzurum BB & Var & Var & Var & Yok \\
\hline 10. Eskişehir BB & Var & Var & Var & Yok \\
\hline 11. Gaziantep BB & Var & Var & Var & Yok \\
\hline 12. Hatay BB & Var & Yok & Yok & Yok \\
\hline 13. İstanbul BB & Var & Var & Var & Yok \\
\hline 14. İzmir BB & Var & Var & Yok & Yok \\
\hline 15. Kahramanmaraş BB & Var & Var & Yok & Yok \\
\hline 16. Kayseri BB & Var & Var & Yok & Yok \\
\hline 17. Kocaeli BB & Var & Var & Yok & Yok \\
\hline 18. Konya BB & Var & Var & Var & Var \\
\hline 19. Malatya BB & Var & Var & Var & Var \\
\hline
\end{tabular}




\begin{tabular}{|c|c|c|c|c|}
\hline 20. Manisa BB & Var & Var & Yok & Var \\
\hline 21. Mardin BB & Var & Var & Yok & Yok \\
\hline 22. Muğla BB & Var & Var & Yok & Yok \\
\hline 23. Mersin BB & Var & Var & Yok & Yok \\
\hline 24. Ordu BB & Var & Var & Yok & Var \\
\hline 25. Sakarya BB & Var & Var & Var & Yok \\
\hline 26. Samsun BB & Var & Yok & Var & Var \\
\hline 27. Şanlıurfa BB & Var & Yok & Yok & Var \\
\hline 28. Tekirdağ BB & Var & Var & Var & Var \\
\hline 29. Trabzon BB & Var & Var & Var & Var \\
\hline 30. Van BB & Var & Var & Yok & Var \\
\hline Toplam & $30 / 30$ & $30 / 27$ & $30 / 18$ & $30 / 17$ \\
\hline
\end{tabular}

Belediyelerin ilgili paydaşlarına yönelik hangi hizmetleri sunduğuna yönelik analize yer verilmiştir. Buna göre belediyelerin tamamı vatandaşlara yönelik (G2C; 30) hizmet sunmaktadır. Belediyelerin hizmet sunduğu bir başka paydaş da iş dünyasıdır (G2B). 27 belediyenin iş dünyasına yönelik hizmet sunduğu görülürken geri kalan üç belediyenin ise bu yönde hizmet sunmadığı saptanmıştır. Etkileşim içerisinde bulunduğu diğer kamu kurumlarına (G2G) ise 18 belediyenin hizmet sunduğu diğer taraftan 12 belediyenin ise bu konuda herhangi bir hizmet sunmadığ1 tespit edilmiştir. Son olarak belediyelerin kamu kurum çalşsanlarına (G2E) ise 17 belediye hizmet sunarken geriye kalan 13 belediyenin ise bu noktada hizmet sunmadığ bulgulanmıştır.

Bulgularda dikkat çeken husus, belediyelerin tamamının vatandaşa yönelik hizmetleri eksiksiz sunmada gösterdikleri hassasiyettir. Önemli paydaşlardan birisi olan iş dünyasına yönelik ise sadece Hatay Büyükşehir Belediyesi, Samsun Büyükşehir Belediyesi ve Şanlıurfa Belediyesi dişında tüm belediyelerin bu kesime yönelik e-hizmetlere yer vermesi dikkat çekicidir. Özellikle iş dünyasının birkaç temel hizmette de olsa belediyeye gitmeksizin bu hizmetlerden yararlanmaları hız ve verimlilik açısından önemlidir. Belediyelerin kamu kurumlarına yönelik hizmetlerde ve kamu çalışanlarına yönelik hizmetlerde ise vatandaşlar ve iş dünyasına nazaran daha az belediyenin e-hizmet sunduğu görülmektedir. Bu bulgu hem kamu kurumlarına hem de kamu çalsşanlarına hizmet sunmada geleneksel yöntemleri kullandıkları şeklinde yorumlanabilir.

Tablo 7. E-Devlet Hizmetlerinin Büyükşehir Belediyelerinin Kurumsal Web Sayfalarındaki Dağılımı

\begin{tabular}{|l|c|c|c|}
\hline $\begin{array}{l}\text { BELEDİYELERİN KURUMSAL } \\
\text { WEB SAFYALARI }\end{array}$ & BİLGİLENDİRME & ETKİLEŞİM & İŞLEM \\
\hline 1. Ankara BB & Var & Var & Var \\
\hline 2. Adana BB & Var & Var & Var \\
\hline 3. Antalya BB & Var & Var & Var \\
\hline 4. Aydın BB & Var & Var & Var \\
\hline 5. Balıkesir BB & Var & Var & Yok \\
\hline 6. Bursa BB & Var & Var & Var \\
\hline 7. Denizli BB & Var & Var & Var \\
\hline 8. Diyarbakr BB & Var & Var & Var \\
\hline 9. Erzurum BB & Var & Var & Var \\
\hline 10. Eskişehir BB & Var & Var & Var \\
\hline 11. Gaziantep BB & Var & Var & Var \\
\hline 12. Hatay BB & Var & Var & Var \\
\hline 13. İstanbul BB & Var & Var & Var \\
\hline 14. İzmir BB & Var & Var & Var \\
\hline 15. Kahramanmaras BB & Var & Var & Var \\
\hline 16. Kayseri BB & Var & Var & Var \\
\hline 17. Kocaeli BB & Var & Var & Var \\
\hline 18. Konya BB & Var & Var & Var \\
\hline 19. Malatya BB & Var & Var & Var \\
\hline 20. Manisa BB & Var & Yok & Var \\
\hline 21. Mardin BB & Var & Yok & Var \\
\hline 22. Muğla BB & Var & Var & Var \\
\hline 23. Mersin BB & Var & Var & Var \\
\hline
\end{tabular}




\begin{tabular}{|l|c|c|c|}
\hline 24. Ordu BB & Var & Var & Var \\
\hline 25. Sakarya BB & Var & Var & Var \\
\hline 26. Samsun BB & Var & Var & Var \\
\hline 27. Şanluurfa BB & Var & Var & Var \\
\hline 28. Tekirdağ BB & Var & Var & Var \\
\hline 29. Trabzon BB & Var & Var & Var \\
\hline 30. Van BB & Var & Var & Var \\
\hline TOPLAM & $\mathbf{3 0 / 3 0}$ & $\mathbf{3 0 / 2 8}$ & $\mathbf{3 0 / 2 9}$ \\
\hline
\end{tabular}

Belediyelerin kurumsal web sayfalarından sundukları "e" hizmetler e-devlet olgunlaşma modeline göre kategorilendirildiğinde belediyelerinin tamamının bilgilendirme (30; \%100) adımı çerçevesinde hizmet sundukları görülmektedir. Etkileşim adımında ise belediyelerden 28’i (28; \%093,33) etkileşim adımı kapsamında hizmet sunarken 2'si (2; \%6,66) (Manisa Büyükşehir Belediyesi ve Mardin Büyükşehir Belediyesi) etkileşim aşaması kapsamında hizmet sunmadığı saptanmaktadır. İşlem aşamasını kapsayan hizmetlerde ise araştırma kapsamındaki belediyelerin 29'unun (29; 96.6) işlem aşaması kapsamında hizmet sunduğu sadece 1 (1;\%3.33) belediyenin (Balıkesir Büyükşehir Belediyesi) işlem aşaması kapsamında hizmet sunmadığ1 saptanmıştır.

Bulgulardan hareketle büyükşehir belediyelerinin tamamının kurumsal web sayfalarında e-devlet olgunlaşma aşamalarından birinci adım olan "bilgilendirme"yi gerçekleştirdiği ve buna ilişkin hizmetleri sundukları görülmektedir. Bunu 29 büyükşehir belediyesinin "işlem" aşamasını, 28 büyükşehir belediyesinin ise paydaşlarıyla "etkileşim" sağlamada e-hizmet uygulamalarından yararlandıkları görülmektedir.

Tablo 8. E-Belediye Hizmetlerinin E-Devlet Platformundaki Görünümü

\begin{tabular}{|l|c|c|c|}
\hline E-DEVLET PORTALI & BİLGİLENDİRME & ETKİLEŞİ & İŞLEM \\
\hline 1. Ankara BB & Var & Var & Yok \\
\hline 2. Adana BB & Var & Yok & Yok \\
\hline 3. Antalya BB & Var & Var & Yok \\
\hline 4. Aydın BB & Var & Yok & Yok \\
\hline 5. Balıksir BB & Var & Yok & Yok \\
\hline 6. Bursa BB & Var & Yok & Yok \\
\hline 7. Denizli BB & Var & Var & Yok \\
\hline 8. Diyarbakur BB & Var & Yok & Var \\
\hline 9. Erzurum BB & Var & Var & Var \\
\hline 10. Eskişehir BB & Var & Yok & Yok \\
\hline 11. Gaziantep BB & Var & Yok & Yok \\
\hline 12. Hatay BB & Var & Yok & Yok \\
\hline 13. İstanbul BB & Var & Var & Var \\
\hline 14. İzmir BB & Var & Yok & Yok \\
\hline 15. Kahramanmaraş BB & Var & Var & Yok \\
\hline 16. Kayseri BB & Var & Var & Yok \\
\hline 17. Kocaeli BB & Var & Yok & Yok \\
\hline 18. Konya BB & Var & Var & Yok \\
\hline 19. Malatya BB & Var & Var & Yok \\
\hline 20. Manisa BB & Var & Yok & Yok \\
\hline 21. Mardin BB & Var & Yok & Yok \\
\hline 22. Muğla BB & Var & Yok & Yok \\
\hline 23. Mersin BB & Var & Yok & Yok \\
\hline 24. Ordu BB & Var & Yok & Yok \\
\hline 25. Sakarya BB & Var & Var & Yok \\
\hline 26. Samsun BB & Var & Yok & Yok \\
\hline 27. Şanlıurfa BB & Var & Yok \\
\hline 28. Tekirdağ BB & Var & Yok \\
\hline 29. Trabzon BB & & & Yok \\
\hline 30. Van BB & TOPLAM & Vok & Yok \\
\hline
\end{tabular}


Araştırma da büyükşehir belediyelerinin e-devlet platformu üzerinde bilgilendirme, etkileşim ve işlem aşamaları kapsamında hangi hizmetleri sunduğu da sorgulanmıştır. Buna göre belediyelerin tamamı (30; $\% 100$ ) e-devlet platformu üzerinden vatandaşları bilgilendirmektedir. E-devlet platformu üzerinde etkileşim aşamasında ise 11 belediyenin $(11 ; 36.6)$ bu kapsamda hizmet sunduğu görülürken; işlem aşamasında ise $3(3 ; \% 10)$ belediyenin hizmet sunduğu belirlenmiştir. E-devlet platformu üzerinden işlem yapabilme olanağ1 Diyarbakır Büyükşehir Belediyesi, Erzurum Büyükşehir Belediyesi ve İstanbul Büyükşehir Belediyesi tarafindan vatandaşlarına sunulduğu görülmektedir.

Belediyelerin sunmuş oldukları hizmetler değerlendirildiğinde kurumsal web sayfalarından "bilgilendirme", "etkileşim" ve "işlem" kapsamındaki hizmetleri daha etkin bir biçimde sundukları görülmektedir. Öte yandan e-devlet platformu üzerinde ise "bilgilendirme" kapsamındaki hizmetler belediyelerin tümünde yer almasına karşın "etkileşim" ve "işlem" kapsamındaki hizmetlere yeterince yer verilmediği görülmüştür. E-devlet olgunlaşma aşamasının son aşaması olan bütünleşme ya da diğer adıyla tek duraktan hizmet sunumunun büyükşehir belediyeleri tarafından yeterince dikkate alınmadığı ve bu konuda belediyelerin yetersiz kaldığ1 görülmektedir. Buna yönelik politikalar geliştirmeleri ve web sayfasında sundukları hizmetleri e-devlet platformuna taşımaları modern yönetim anlayışının gereklilikleridir.

\section{Sonuç ve Öneriler}

Türk kamu yönetiminde hizmetlerin yürütülmesi, ilgili hedef gruplara ulaştırllmasinda ve yerel yönetimlerin işleyişini etkin ve verimli bir şekilde gerçekleştirmesi açısından bilgi ve iletişim teknolojileri temelli e-belediye uygulamalarının hangi amaçla ve ne şekilde kullanıldığ açısından tespitler yapılarak; belediyelerin e-devlet ve e-belediye uygulamalarının kullanımı ve tasarlanmaları modern yönetim anlayışına uygun bir çerçevede gerçekleşip gerçekleşmediği ortaya koymayı amaçlayan betimleyici bir araştırmadır.

Araştırmada elde edilen bulgular kapsamında, İç İşleri Bakanlığı bünyesinde oluşturulan e-belediye platformuna üye belediyelerin çoğunlukta olmasına rağmen kamu hizmetlerinin daha sistematik ve daha etkin bir şekilde yerine getirilmesi noktasında bütünlügün sağlanması büyük önem arz etmektedir. Dolayısıyla belediyeler sunmuş oldukları hizmetlerle beraber e-belediye platformuna entegre olmaları gerek hizmetlerin gerekse yönetim-vatandaş arasındaki etkileşimin ve iletişimin tek noktadan, zaman ve mekan kavramı gözetmeksizin gerçekleştirilmesi açısından hayati bir rol üstlenmektedir. Bu açıdan bakıldığında ebelediye platformunun yaygınlaştırilmasında, tanıtılmasında ve hizmetlerin bütünüyle entegre olmasının sağlanmasi gerekmektedir.

Belediyelerin e-belediye uygulamalarına "e-belediye", "e-belediye uygulamaları", "e-belediye hizmetler,", "bilgi edinme”, "interaktif”, "online işlemler", "işlem merkezi”, "e-hizmet", "e-platform”, "çevrimiçi-hizmetler" ve "online işlemler-borç ödeme" başlıkları altında web sitelerinde yer vermektedirler. Bunların dışında Mardin Büyükşehir Belediyesi ve Erzurum Büyükşsehir Belediyesi ebelediye uygulamalarına belirli bir isimle yer vermediği uygulama kapsamında tespit edilmiştir. $\mathrm{Bu}$ tespitlerden yola çıarak belediyelerin sundukları e-devlet hizmetlerini kurumsal web sayfalarında yer verirken e-belediye uygulamalarını daha belirgin, daha anlaşılır ve erişimi kolay bir şekilde tasarlamaları gerekmektedir.

Araştırma kapsamında elde edilen bulgulardan birisi ise belediyelerin ilgili paydaşlarına sunduğu ehizmetlerdir. Belediyelerin neredeyse tamamı vatandaşlarına ve iş dünyasına yönelik e-hizmetleri eksiksiz bir biçimde sunduğu görülmektedir. Bunun dışında büyükşsehir belediyelerinden yarısından çoğu da devletten devlete ve kamu çalışanlarına yönelik çeşitli e-hizmetleri sunmaktadır. Bu hizmetlerin sunulması yönetimin ve çalışanlarının görev ve sorumluluklarını etkin ve verimli bir biçimde getirmelerine olanak sağlamaktadır.

Araştırma kapsamında elde edilen bulgulara göre belediyelerin tamamı hem kurumsal web sayfaları üzerinden hem de e-devlet platformu üzerinden bilgilendirmeye yönelik e-hizmetler sunmaktadır. Etkileşime yönelik hizmet sunumunda ise belediyelerin tamamına yakını (\%93) kurumsal web sayfalarında bu hizmetlere yer vermekte iken; e-devlet platformunda bu sayı düşmektedir (\%36). İşleme dönük hizmetlerde de belediyelerin tamamına yakını (\%96) bu hizmetlere yer verirken; e-devlet platformu üzerinden az sayıda belediye (\%10) işleme yönelik hizmet sunmaktadır. 
Araştırma kapsamında elde edilen veriler ışı̆̆ında şu öneriler getirilebilir:

- Belediyelerin kendi web sayfalarında sundukları e-belediye uygulamalarını e-belediye platformuna taşımalıdır.

- Belediyelerin sundukları e-devlet/e-belediye hizmetleri kurumsal web sayfalarnnda daha belirgin, anlaşılır ve erişimi kolay bir şekilde tasarlamalıdır.

- Belediyelerin etkileşimde bulunduğu tüm paydaşlarına yönelik hizmetler geliştirmeli ve bunları entegre bir biçimde sunmalıdır.

$\mathrm{Bu}$ bulgular kapsamında belediyeler kurumsal web sayfalarındaki ilgili hizmetlerini e-devlet platformuna taşımaları hem hizmetlerin bütünlüğü açısından hem de hizmetlere daha kolay ulaşım sağlanmaları gerçekleştirilmiş olacaktır. Araştrrma Türkiye'de faaliyet gösteren 30 büyükşehir belediyesi ile sınırlandırılmıştı. Bundan sonraki çalışmalarda ilin merkez belediyelerini içine alan bir araştırma yapılabilir. $\mathrm{Bu}$ sayede ilgili belediyeler arasında karşılaştırma yapilarak belediyelerin var olan durumu tespit edilebilir ve geliştirilmesine yönelik stratejiler geliştirilmesine 1şık tutar. Son olarak, yapılan bu araştırma da e-hizmet sunan belediyelerin bunu hangi boyutlarda sunduğuna odaklanılmıştır. Bundan sonraki çalışmalarda hizmet alan vatandaşların hizmetlere erişim düzeyi ve memnuniyetine yönelik alan araştırmalarına literatürde daha çok yer verilebilir.

\section{Extended Abstract}

Municipalities in Turkish public administration have had variety of changes in in their organizational structure and place in social life; in parallel with the development and changes in social life. Compared to the central government-citizen relationship, the most significant difference in the relationship between local governments and citizens is the spatial and social difference between local government and citizens. This difference positions local governments as a complementary element within the central government. Despite these characteristics, in Turkish public administration, it comes to the fore as a paper-based, bureaucratic structure based on formalities, which is inherent in traditional management understanding, which negatively affects the interaction and communication between the administration and the relevant publics. Developments in information and communication technologies, especially since the 1980s, have led to radical changes in service delivery in public administration and have been a promising idea in solving bureaucratic-based problems. In this direction, the e-government application in the national sense and the e-municipality application in the local sense play a vital role in realizing the modern management approach with the aim of effective and efficient service

In the theoretical part of the study, information was given about the concepts of e-municipality and egovernment by explaining the transformation of traditional municipalism to the concept of e-municipality, which is defined as the modern management approach in the administrative sense, where information and communication technologies are at the forefront. In the practical part of the study e-services which are offered by the 30 metropolitan municipalities in Turkey were examined within the scope of information, interaction, transaction and integration stages, which are called e-government maturity model / development stages in the literature, by subjecting them to content analysis method on both corporate web pages and e-government platform between December 02, 2020 and December 08, 2020.

Within the scope of this research, it is first examined whether the examined municipalities are members of the common "e-municipality" platform for all municipalities, which was first implemented by the Ministry of Internal Affairs. Then, the names of the e-municipality services in the corporate web pages of the municipalities were examined and the quantitative analysis of the e-municipality applications offered through both the corporate web pages and the e-government platform were included. Another issue examined within the scope of the study is the determination of specific applications of municipalities towards citizens, business world, government and public employees. Lastly, by analyzing the e-services offered by the municipalities both on the corporate website and on the e-government platform; Important determinations have been made regarding whether the services available on the corporate web page are available on the e-government platform.

According to the analysis made in the research, it was determined that 18 of the 30 municipalities examined were members of the e-municipality platform. On the corporate web pages of municipalities, 
the e-municipality applications are "e-municipality", "e-municipality applications", "e-municipal services", "e-municipality system", "e-municipality-obtaining information", "e-municipality- interactive "emunicipality-online transactions", "e-transaction center", "e-service, e-platforms-online services" "online transactions" and "online transactions-debt payment" transactions. They provide a total of 557 e-services through their corporate web pages and 184 e-services through e-government. While all of the municipalities $(30 ; \% 100)$ provide services to citizens and almost all of them $(27 ; \% 89)$ to the business world through corporate web pages, it is seen that this situation decreases in applications for the state (18; $\% 59)$ and public employees $(17 ; \% 56)$.

Within the scope of the findings obtained in the research, it is important for all municipalities to participate in the "e-municipality" platform and to carry all services they offer to this platform, considering the "e-government" example, to provide the e-municipality system in a holistic manner, in terms of the use of services, easy access and reliability. On the other hand, while all of the municipalities provide services for information (30; \%100), and almost all of them provide services for the interaction $(28 ; \% 93)$ and transaction $(29 ; \% 96)$ stages, this situation focuses on the provision of services for the information stage on the e-government platform. It is noteworthy that there are fewer applications for the interaction and transaction phase offered through the e-government platform. At this point, municipalities should transfer the services they provide through corporate web pages to the e-government platform

Based on the findings obtained as a result of the analysis made within the scope of this research, it can be suggested that municipalities should be integrated into the e-municipality platform with their services, and that they should be easy to reach, understand and be specific when naming and positioning emunicipality applications.

\section{Kaynakça}

Alhomod, M. S., \& Shafi , M. M. (2012). Best practices in e-government: a review of some innovative models proposed in different countries. International of Electrical and Computer Sciences, 12(1), 1-6.

Andersen, K. V., \& Henkriksen, H. Z. (2006). E-government maturity models: extension of the Layne ve Lee model. Government Information Quarterly, 23, 236-348.

Backus, M. (2001). E-Govarnance and developing countries: introduction and examples. IICD.

Caldow, J. (2001). Seven e-government leadership milestones. M. E. Milner (Dü.), Vision and Revision in. (s. 17-39). London: Routledge.

Chun, A., Shulman, S., Rodrigo, S., \& Hovy, E. (2010). Government 2.0: making connections between citizens, data and government. Information Polity, 15, 1-9.

Çoban, H. (1996). Bilgi toplumuna planl geçmek için stratejik planlama ve yönetim sistemi uygulaması. Devlet Planlama Teşkilatı.

Çoruh , M. (2009). Kent bilişim sistemi ve e-belediye. M. Akgül , E. Derman, U. Çağlayan , \& U. Özgit (Dü.), XI. Akademik Bilişim Konferansı Bildirileri Kitabı. içinde 11-13 Şubat. Ankara: Nokta Matbaacilık.

DeBenedictis, A., Howell , W., Figueroa, R., \& Royy, A. B. (2002). E-Government defined: an owerview of the next big information techonology challange. Issues In Information Systems, LACIS 3, 130136.

Deloitte ve Touche. (2004). At the down of e-government: the citizens as customer. Deloitte Consulting and Deloitte\&Touche.

Devadoss, P. R., Pan, L. S., \& Huang , C. J. (2002). Structurational Analysisod e-government initiatieves: a case study of SCO. Decision Support Systems, 34, 253-269.

Dönmez, M. (1995). Türkiye'de belediyeciliğin tarihsel gelişimi. Türk İdare Dergisi, 406, 165-174.

Elias, P., \& Hamid, J. (2007). Challenges to e-municipality in the developing countries. In First International Conference on Electronic Municipality, Ekim, s. 16-17. Tahran.

Evans, D., \& Yen, D. C. (2006). E-Government: evolving relationship of citizens and government, domestic and international development. Government Information Quarterly, 23, 207-235.

Fountain, J. E. (2001). Building the virtual state: information techonology and institutional change. Washington D.C: Brookings Institutional Press. 
Garson, D. (2004). The promise of digital government. P. Alexei, \& G. G. David (Dü.), Digital Government: Principles and Best Practices in. (s. 2-15). Hersey: İdea Group Publishing.

Gottschalk, P. (2008, 08 21). Maturity levels for interoperability in digital government. Norwegian School of Management, 17. Oslo, Norveç: Nydalsveien.

Henden , B., \& Henden, R. (2005). Yerel yönetimlerin hizmet sunumundaki değişim ve e-belediyecilik. Elektronik Sosyal Bilimler Dergisi, 4(14), 48-66.

Hiller, J. S., \& Belanger, F. (2001). Privacy strategies for electronic government. A. M. Abramson, \& E. G. Means (Dü) in, E-Government 200 (s. 162-198).

Holden, H., Donald, F., \& Patricia , D. (2003). Electronic government at the local level. Public Performance \& Management Review, 26(4), 325-344.

Howard, M. (2001). E-Government across the globe: how will "e" change government. Government Finance Review, 6-9.

İç İşleri. (2020). 08 18, 2020 tarihinde İç İşleri Bakanlığı: https://www.icisleri.gov.tr/ adresinden alınd1

İnce, N. M. (2001). Elektronik devlet-kamu hizmetlerinin sunulmasinda yeni imkanlar. Ankara: DPT Yayınları. Janowski, T. (2015). Digital government evolution: from transformation to contextualization. Government Information Quarterly, 32, 221-236.

Joshi , P. R., \& Shareeful, I. (2018). E-Government maturity model for sustainable e-government services from the perspective of developing countries . Sustainability, 3-28.

Kaya Bensghir, T. (2000). Bilgi toplumu bakanlı̆̆1 kuruluşu üzerine: Mekanik bir örgüt mü? Amme idaresi dergisi, 33(4), 33-62.

Layne, K., \& Lee, J. (2001). Developing fully functional e-government: a four stage model. Governmen Information Quarterly, 18, 122-136.

Lee, G., \& Kwak, H. Y. (2012). An open government maturity model for social media based public engagement. Government Information Quarterly, 29, 492-503.

McMillan, L. (2004). Financial relationships between regional and municipal authorities: Insights from the examination of five OECD countries. Institute of Intergovernment Relations.

Mecek, M. (2017). E-Devlet ve e-belediye: kavramsal çerçeve ve Türkiye'de belediye web sitelerine yönelik yapılan çalışmaların incelenmesi. Süleymen Demirel İİ.B.F Dergisi, 22(15), 1815-1851.

Miles, M., \& Huberman, M. (1994). An expanded sourcebook qualitative data analysis second edition. London: Sage Publicitions.

Moon, J. M. (2002). Evolution of e-government among municipalities: rhetoric of reality? Public Administration Review, 62(4), 424-433.

Moon, M., \& Norris, F. (2005). Does managerial orientation matter? The adaption of reinventing government at the municipal level. Info Systems, 15, 43-60.

Nohutçu, A., \& Balc1, A. (2005). Bilgi çăğnda türk kamu yönetiminin yeniden yapılandırlması I. İstanbul : Beta Basım A.Ş.

Nohutçu, A., \& Demirel, D. (2005). Türkiye'de e-devlet uygulamaları . Türk İdare Dergisi, 447, 35-57.

OECD. (2003). The e-government imperative . Paris: OECD Publications Service.

Özüpek, M. (2003). Belediyelerde halkla iliskiler. Konya: Eğitim Yayınevi.

Reddick, G. C. (2004). A two stage model of e-government growth: theories and empricial evidence for U.S cities. Government Information Quarterly, 21, 51-64.

Roblek, V., Bach, P., Mesko, M., \& Bertoncel, T. (2020). Best practices of the social innovation in the framework of the e-government evolution. Amfiteatru Economic, 22(53), 275-302.

Ronaghan , S. A. (2001). Bencmarking e-government: a global perpective ". 11 07, 2020 tarihinde https://publicadministration.un.org/egovkb/portals/egovkb/documents/un/english/pdf. adresinden alind1

Sakal, M. (2000). Türkiye'de yerel yönetimlerde yeniden yapılanma sorunu: tarihsel perspeftikten bir değerlendirme. Süleyman Demirel Üniversitesi İI. B.F Dergisi, 5(1), 119-140.

Sayımer, İ. (2015). Electronic government in public Administration: an assesment of local government web sites in Turkey. International Journal of e-business and e-government studies, 7(2), 1-16. 
Scoot, K. (2005). Assesing the quality of municipal government web sites. Stata and Local Government Review, 27(2), 151-165.

Shakooh, A. K., Saghafi, F., \& Abdollahi, A. (2008). A proposed model for e-government maturity. 711 Nisan 2008. Suriye: IEEE.

Siau, K., \& Yuan, L. (2005). Synthesizing e-government stage models- a meta-synthesis based on mateethnography approach. Industrial Managemen Data Systems, 105(4), 443-458.

Şahin, A. (2007). Türkiye'de e-belediye uygulamaları ve Konya örneği . Erciyes Üniversitesi İ.I.B.F Dergisi, 29 temmu a aralk. 2007, 161-189.

Tamer, M. (1995). Yerel yönetimlerin yeniden düzenlenmesi. Kamu Yönetimi Disiplini Semposyumu Bildirileri, Kasim 1995, s. 244-255.

Tarhan, A. (2007). Halkla ilişkilerde tanıma ve tanıtma aracı olarak internet: belediyelerin web sayfaları üzerine bir analiz. Selçuk Illetişim, 4(4), 75-95.

Tarhan, A. (2010). Kamu yönetiminde halkla iliskiler. Konya: Şelale Ofset.

Tavşancil, E., \& Arslan, E. (2001). Söz̧el yaz̨l ve diğer materyaller için içerik analizi ve uygulama örnekleri. İstanbul: Epsilon Yayıncilik.

Tortop, N. (1985). Yönetim sistemimiz içinde belediyelerin önemi, sorunları ve yeni düzenlemeler. Amme İdaresi Dergisi, 18(4), 3-12.

United Nations. (2012). E-Government survey 2012: e-government for the people. New York: Printed at the United Nations.

United Nations. (2003). World public sector reports 2003: e-goverment at the crossroads. United Nations. New York: Department of Economic and Social Affairs. 24.

Wescott, C. G. (2001). Asian journal of political science. E-Government in the Asia Pasific Region, 9(2), 1-

West, M. D. (2004). E-Government and the transformation of service delivery and citizen attitudes. Public Administration Review, 64(1), 15-27.

Worldbank. (2002). The handbook for developing countries. InfoDev and The Center For Democracy and Techonology. 11 07, 2020 tarihinde www.infodev.org/sites/default/files/resource/ adresinden alındı

www.tbb.gov.tr. (2020). Türkiye Belediyeler Birliği. 12 08, 2020 tarihinde http://www.tbb.gov.tr adresinden alındı

Yalçındağ, S. (1987). Kamu sektöründe halkla ilişkiler uygulamaları ve sorunlarının genel görünümü. Halkla İlişkiler Semposyumu-87 (s. 55-84). Ankara Üniversitesi Basın Yayın Yükokulu Yayınlant.

Yalçındağ, S. (1991). Yerel yönetimlerde yeniden yapılanma. Amme İdaresi Dergisi, 24(3), 123-152.

Yavuz, F. (1996). Türk mahalli idarelerin yeniden düzenlenmesi üzerinde bir arasttrma. Ankara Üniversitesi Basımevi. 